\title{
Testing Multi Bubbles for Commodity Derivative Markets: A Study on MCX
}

\begin{abstract}
Ayben Koy ${ }^{\mathrm{a}}$
Abstract: Due to their volatility differences, yield differences and low correlations with equity markets, metal futures are held for diversification in the international investors' portfolios. Beginning with dot.com bubble and following global crisis, the mutual movement of equity markets caused investors to canalize alternative investment vehicles. The study aims to investigate if there are bubbles in metal futures in The Multi Commodity Exchange of India Limited (MCX) related the period beginning from January 2010 to August 2017 for copper, lead, nickel and zinc; and March 2010 to August 2017 for aluminum in a weekly data range. Using Sup Augmented Dickey Fuller (SADF) and Generalized Sup Augmented Dickey Fuller (GSADF) tests, no evidence on bubble could be found in any metal market in the used MCX sample. The precious metal markets are out of the sample because of their relatively high volatility.
\end{abstract}

Keywords: Bubble, Commodity Market, Metal Market, SADF, GSADF

JEL: G00, G10, G15, C58

Received: 14 December 2017 Revised: 31 January 2018 Accepted: 19 March 2018

\section{Introduction}

For emerging economies, commodity derivatives markets have a significant place in the world economy, such as the future price determination and hedging, as well as the transfer of developed market characteristics and the development of the local financial infrastructure. On the other hand, due to their volatility differences, yield differences and low correlations with equity markets, metal futures are held for diversification in the international investors portfolios (Arouri et al., 2013; Arouri \& Nguyen: 2010; Conover et al., 2010; Daskalaki \& Skiadopoulos, 2011; Hammoudeh et al., 2013.) Beginning with dot.com bubble and following global crisis, the mutual movement of equity markets causes investors to canalize alternative investment vehicles such as commodity based derivatives. The growing interest of investors in commodity derivative markets may also lead prices away from the random walking process.

The separations of financial assets from random walking process called price bubble, and also expressed as the separation of a financial asset from its real value. Durability, scarcity and common beliefs associated with the behavioral finance are the three main actors cause price bubbles (Tirole, 1985). While the price bubbles mostly have been seen in financial assets and real estate, the first historical example of price bubble is Tulipmania. In the 1630s, the Dutch people devoted themselves to tulip cultivation and almost all of the arable fields were turned into tulip gardens. At the beginning of 1637 , Semper Augustus was sold to the 10,000 Guilder. 10,000 Guilder could be paid by all but a few dozen of people in the Netherlands and coinciding with the price of the most beautiful houses in Amsterdam (Dash, 1999). In 20th century, real estate bubbles took place in US., Switzerland and Japan. While the real estate bubble is recognized in US, investors began to interest with the equity market. This interest caused another anomaly in financial markets that 
rapidly rising New York Stock Exchange fell $12.8 \%$ on October 24, 1929. In late 1990s, the interest on US internet based companies stocks has been seen as rapid rise. This rapid rise collapsed in 2001. Finally, the last big bubble effected whole world economy is Mortgage crisis in 2008.

In this research investigating the existence of financial asset bubbles, commodity markets are selected as sample. The need to reduce the problems of the risky, unpredictable and unstructured agricultural industry has raised the need for the development of today's commodity derivatives. Agricultural commodity markets have a very complex mechanism involving farmers, farm owners, processors, distributors, packers, wholesalers and retailers. Moreover, it is difficult to manage risks such as extreme weather changes in agriculture, disease, natural disasters and government policies. The products that are most demanded in the world economy and whose prices are discussed are undoubtedly energy commodities. Beyond being the driving force of trade and industry, energy products that meet the needs of households are essential today in all areas of life. Firms which demand any amount of energy are at significant risk of changing prices. There are many common expectations of trading parties in the purchase and sale of any physical commodity in world trade. Expectations such as credibility, timeliness, honesty and flexibility lead to the standardization of the trade.

The use of commodity derivatives in terms of businesses leads to increased competitive advantage and profitability by using various price strategies. Enterprises using commodity derivatives in the supply of raw materials can fix production costs. Unpredictable, frequent and large fluctuations in commodity prices lead to managerial difficulties and costing problems when using these items in manufacturing enterprises, where commodity derivatives are not used without cost estimates.

Most of the transactions carried out in today's derivative markets are based on financial investment. Transferring information for future prices to all investors is an important function of futures markets. Those who collect and analyze information about the future state of the world economy will obtain returns on their investment in this information. In the absence of a futures market, investors use the information they analyze to determine the spot price for the following period. The fact that informed investors have different expectations for the future price will also cause the investor with knowledge to get a return on the market. In advanced derivative markets, the future prices are made known to all investors and the information of the investor who has knowledge is transferred to the investor who does not have knowledge.

The interest among commodity markets and commodity derivative markets encountered with speculative movements like other investment instruments over time. As exemplified in the literature part, bubbles are found in many types of commodity markets as precious metals (Baur \& Glover, 2012), agriculture (Diesteldorf et al., 2016) or oil products (Su et al., 2017). In the study, the bubbles in non-precious metals as aluminum, copper, lead, nickel and zinc are detected in a growing and known commodity futures market: The Multi Commodity Exchange of India Limited (MCX). India, which have a growing share of the world economy with features such as rich natural resources, labor force, have an important place among the world's derivative markets too. National Stock Exchange of India is the 2nd derivative market with it's 2.47 billion contracts' volume and MCX is the 20th derivative market with it's 0.20 billion contracts' volume in 2017 in the world.

These selected group have the most basic inputs of industrial production. They are used in vehicles, military applications, packaging, construction, electrical-electronics, chemical and steel industries.

\section{Literature}

Different types of tests have been developed to clarify the bubbles beginning with variance bound tests (Shiller, 1981) and runs test (Santony, 1987). At the same time, there are numerous studies in the literature describing the suddenly big movements in financial asset prices and real estate prices (Bettendorf \& Chen, 2013; Phillips, Shi \& Yu, 2015, Escobari \& Jafarinejad, 2015; Korkmaz, Erer \& Erer, 2016) However, the number of works on bubbles related with spot or futures commodity prices is limited. Especially GSADF test used in the study is a very new model developed by Philips et al. in 2015. 
Gilbert (2009), Gutierrez (2013), Areal et al. (2014), Etienne, Irwin, and Garcia (2014), and Diesteldorf et al. (2016) test bubbles in agricultural commodity markets. Gilbert (2009) and Gutierrez (2013) find bubbles for four markets. Markets as fruits, meat and seafood have no evidence on bubbles in Areal, Balcombe and Rapsomanikis (2014). Etienne et al. (2014) find evidence on 10 of 12 commodities. Diesteldorf et al. (2016) use GSADF test to investigate the presence of bubbles in ten agriculture commodity prices. One to three bubble periods are found for six types of commodities in their study.

Gold is a valuable investment instrument, beyond being an industrial asset. Bubbles in gold prices are analyzed by Baur and McDermott (2010), Baur and Glover (2012) and Long et al. (2016). They all find evidence on the bubbles in gold prices. The other type of commodities which have importance in the world economy are energy products such as crude oil and natural gas. Su et al. (2017) find six bubbles in oil in a 21 years period ending 2016.

In recent years, studies in the literature have included bubble analysis in similar metal market samples as the sample used in this study. Ferretti et al. (2015) detect bubbles on London Metal Exchange (LME) for six non-ferrous metal prices. In another study, the global iron ore prices beginning from 1980 to 2016 are analyzed by GSADF in Su et al. (2017). Four different bubbles in the years 2005, 2006, 2007 and 2008 are found in the model.

\section{Data and Model}

MCX is a commodity derivatives exchange in India which started operations in November 2003. MCX is not only an important metal and energy derivatives exchange, some agricultural derivatives as black pepper, cotton, crude palm oil, and mentha oil are also have being traded. In the study, metal futures closing prices used begin from January 2010 to August 2017 (398 observations) for copper, lead, nickel and zinc; and March 2010 to August 2017 (389 observations) for aluminum in a weekly data range.

\subsection{Sup Augmented Dickey Fuller Test}

SADF, which is one of the right-tailed unit root tests is developed by Philips, Si and Yu (2011). The analysis allowed for a null random walk process with an asymptotically negligible drift.

$$
\begin{aligned}
& \text { yt }=\mathrm{d} T^{-\eta}+\emptyset \mathrm{yt}-1+\varepsilon_{t}, \varepsilon_{t} \sim^{i i d} \mathrm{~N}\left(0, \sigma^{2}\right), \emptyset=1 \\
& \mathrm{~d}=\text { constant, } \\
& \mathrm{T}=\text { sample size, } \\
& \text { ワ }>1 / 2
\end{aligned}
$$

The recommended empirical regression model for bubble detection in formula (1) above includes an intercept but no fitted time trend in the regression. Suppose a regression sample starts from the $r_{1}^{\text {th }}$ fraction of the total sample and ends at the $r_{12}^{t h}$ fraction of the sample, where $r_{2}=r_{1}+r_{w}$ and $r_{w}$ is the (fractional) window size of the regression. The empirical regression model can be written as follows:

$$
\begin{aligned}
& \Delta \mathrm{yt}=\propto_{r_{1} r_{2}}+\beta_{r_{1} r_{2}} y_{t-1}+\sum_{\mathrm{i}=1}^{\mathrm{k}} \varphi_{r_{1} r_{2}}^{i} \Delta \mathrm{y}_{t-i}+\varepsilon_{t} \\
& \mathrm{k}=\text { lag order, } \\
& \varepsilon_{t} \sim^{\text {iid }} \mathrm{N}\left(0, \alpha_{r_{1} r_{2}}^{2}\right), \\
& \mathrm{T}_{w}=\left\lfloor T r_{w}\right\rfloor=\text { Number of the observations in the regression }
\end{aligned}
$$

ADF statistic (t ratio) based on this regression is signified by $A D F_{r_{1}}^{r_{2}}$ 
This right tailed unit root test estimates the Augmented Dickey Fuller (ADF) model repeatedly on a forward expanding sample sequence conducts a hypothesis test based on the sup value of the corresponding ADF statistic sequence.

$\mathrm{r}_{\mathrm{w}}=$ window size

window size expands from $r_{0}$ to 1.

The ending point of each sample $r_{2}$ is equal to $r_{w}$.

The ADF statistic for a sample that runs from 0 to $r_{2}$ is denoted by $A D F_{0}^{r_{2}}$. The SADF statistic is defined as $\sup _{\mathrm{r} 2 \in[\mathrm{r} 0 ; 1]} A D F_{0}^{r_{2}}$; and is denoted by SADF ( $\left.\mathrm{r}_{0}\right)$.

\subsection{Generalized Sup Augmented Dickey Fuller Test}

The GSADF test continues the idea of repeatedly running the ADF test regression (2) on a sample sequence. However, the sample sequence is broader than that of the SADF test. GSADF test allows the starting point $r_{1}$ to change within a feasible range, which is from 0 to $r_{2}-r_{0}$. GSADF statistic defined to be the largest ADF statistic over the feasible ranges for $r_{1}$ and $r_{2}$, and signified by GSADF( $\left.r_{0}\right)$ (Philips et al., 2012; 2015(a); 2015 (b)).

$$
\begin{array}{ccc}
\operatorname{GSADF}(\mathrm{r} 0)= & \sup \quad\left\{A D F_{r_{1}}^{r_{2}}\right\} \\
& r_{2} \in\left[r_{0}, 1\right] \\
& r_{1} \in\left[0, r_{2}-r_{0}\right]
\end{array}
$$

Including an intercept in the regression model and the null hypothesis is a random walk without drift (i.e. $d T^{-n}$ with $n>1 / 2$ and constant $d$ ), the limit distribution of the GSADF test statistic is can be written as follows:

$$
\sup \left\{\begin{array}{c}
\frac{\frac{1}{2} r_{w}\left[W\left(r_{2}\right)^{2}-W\left(r_{1}\right)^{2}-r_{w}\right]-\int_{r_{1}}^{r_{2}} W(r) d r\left[W\left(r_{2}\right)-W\left(r_{1}\right)\right]}{r_{w}^{\frac{1}{2}}\left\{r_{w} \int_{r_{1}}^{r_{2}} W(r)^{2} d r-\left[\int_{r_{1}}^{r_{2}} W(r) d r\right]^{2}\right\}^{\frac{1}{2}}} \\
r_{2} \in\left[r_{0}, 1\right] \\
r_{1} \in\left[0, r_{2}-r_{0}\right]
\end{array}\right\}
$$

$r_{w}=r_{2}-r_{1}$ and $\mathrm{W}$ is a standard Wiener process.

The asymptotic GSADF distribution depends on the smallest window size $r_{0}$. If total number of observations $(T)$ is small, $r_{0}$ needs to be large enough to ensure there are enough observations for adequate initial estimation. If $\mathrm{T}$ is large $\mathrm{r}_{0}$ can be set to be a smaller number, thus the test does not miss any opportunity to detect an early explosive episode (Phillips, Shi and Yu (2011)).

Random and explosive processes are successfully distinguished from each other in GSADF model. It is a dominant model in analyzing speculative movements and behavioral anomalies in the market.

\section{Empirical Results}

The empirical analysis is composed of three steps. In the first step, the descriptive characteristics as normality and skewness of series are identified. Secondly, the traditionally unit root model ADF (Augmented Dickey Fuller) is used to test the nonstationarity of the series. Lastly, the bubble in prices are analyzed in Eviews 9 programme by the Sup Augmented Dickey Fuller Test (SADF) and Generalized Sup Augmented Dickey Fuller Test (GSADF). 
The descriptive statistics of the variables are shown in Table 1. While copper price and nickel price skewed to the left (left-skewed); the prices of aluminum, lead and zinc skewed to the right (right-skewed).

The kurtosis of the futures price series of aluminum, copper and nickel are less than 3 , then the series have lighter tails than a normal distribution. These series have light-tailed distributions. On the other hand, the kurtosis of the series lead futures prices and zinc futures prices are greater than 3 , then they have heavier tails than a normal distribution. These series have heavier-tailed distributions.

Table 1. Descriptive Statistics

\begin{tabular}{|c|c|c|c|c|c|}
\hline & ALUMINUM & COPPER & LEAD & NICKEL & ZINC \\
\hline Mean & 109.8645 & 389.0437 & 119.0190 & 880.8905 & 121.6814 \\
\hline Median & 109.2000 & 401.8750 & 118.3500 & 904.7000 & 113.3750 \\
\hline Maximum & 131.2000 & 475.4000 & 165.1000 & 1312.500 & 200.8000 \\
\hline Minimum & 88.65000 & 294.2500 & 75.45000 & 534.1000 & 78.30000 \\
\hline Std. Deviation & 7.989995 & 45.77181 & 15.25960 & 176.5652 & 25.20131 \\
\hline Skewness & 0.226836 & -0.357586 & 0.234767 & -0.100498 & 1.129806 \\
\hline Kurtosis & 2.905379 & 2.017216 & 3.220565 & 2.316451 & 3.639984 \\
\hline Jarque-Berra & 3.481091 & 24.49915 & 4.462766 & 8.418333 & 91.46416 \\
\hline Probability & 0.175425 & 0.000005 & 0.107380 & 0.014859 & 0.000000 \\
\hline Sum & 42737.30 & 154839.4 & 47369.55 & 350594.4 & 48429.20 \\
\hline Sum. Sq. Dev. & 24769.93 & 831738.4 & 92442.38 & 12376580 & 252137.2 \\
\hline Observations & 389 & 398 & 398 & 398 & 398 \\
\hline
\end{tabular}

In the second step, to test the nonstationarity, the regular ADF test (Dickey Fuller, 1981), is applied to the series. The unit root tests of the variables are shown in Table 2. Except lead in the test with trend and intercept, all results in ADF tests obtain Akaike (AIC) information criteria higher than the critical values. As a result of the test, we failed to reject the hypothesis that the series are stationary.

Table 2. The Results of the Unit Root Tests ADF

\begin{tabular}{|c|c|c|c|c|c|c|c|c|c|}
\hline & \multicolumn{9}{|c|}{$A D F$} \\
\hline & \multicolumn{3}{|c|}{ Akaike (Intercept) } & \multicolumn{3}{|c|}{ Akaike (Trend and Intercept) } & \multicolumn{3}{|c|}{ Akaike (None) } \\
\hline & త్ర & $\begin{array}{l}\stackrel{+}{5} \\
\tilde{w}_{1} \\
\vdash\end{array}$ & 웅 & 尔 & $\begin{array}{l}\stackrel{5}{5} \\
\hat{n}_{1} \\
⺊\end{array}$ & $\frac{0}{0}$ & త్ర & $\begin{array}{l}\tilde{T}_{\tilde{H}} \\
\vdash_{1}\end{array}$ & 음 \\
\hline Aluminum & 0 & -2.790451 & 0.0605 & 0 & -3.241889 & 0.0779 & 4 & 0.476205 & 0.8174 \\
\hline Copper & 0 & -2.480169 & 0.1211 & 0 & -2.594846 & 0.2830 & 0 & 0.039461 & 0.6948 \\
\hline Lead & 0 & -2.319009 & 0.1665 & 0 & -3.793981 & 0.0178 & 0 & 0.130379 & 0.7231 \\
\hline Nickel & 1 & -1.588555 & 0.4875 & 0 & -3.307013 & 0.0666 & 1 & -0.544288 & 0.4809 \\
\hline Zinc & 0 & -0.078097 & 0.9495 & 0 & -2.267181 & 0.4505 & 0 & 1.021134 & 0.9195 \\
\hline $\begin{array}{l}\text { Asymptotic } \\
\text { critical } \\
\text { values }\end{array}$ & & & & & & & & & \\
\hline $1 \%$ & & -3.446608 & & & -3.981343 & & & -2.570800 & \\
\hline $5 \%$ & & -2.868601 & & & -3.421183 & & & -1.941623 & \\
\hline $10 \%$ & & -2.570597 & & & -3.133343 & & & -1.616164 & \\
\hline
\end{tabular}

In the third step, the price bubbles in MCX commodity markets identified with SADF and GSADF tests. The results of SADF and GSADF tests are given on Table 3. The statistics are compared with the critical values obtained from the Monte Carlo simulation with 1000 replications for each observation. 
Table 3. Test Statistics for SADF and GSADF

\begin{tabular}{|c|c|c|c|c|}
\hline & & Finite Sam & cal Values & \\
\hline & Test Stat. & $90 \%$ & $95 \%$ & $99 \%$ \\
\hline ALUMINUM & Window size: 39 & & & \\
\hline SADF & $\begin{array}{l}-0.162794 \\
(0.6980)\end{array}$ & 1.239582 & 1.581463 & 2.002917 \\
\hline GSADF & $\begin{array}{l}0.312490 \\
(0.9990)\end{array}$ & 2.007932 & 2.235417 & 2.924801 \\
\hline COPPER & Window size: 40 & & & \\
\hline SADF & $\begin{array}{l}0.595962 \\
(0.3070) \\
\end{array}$ & 1.195182 & 1.448958 & 2.108712 \\
\hline GSADF & $\begin{array}{l}0.932452 \\
(0.7070) \\
\end{array}$ & 2.014128 & 2.265443 & 2.924275 \\
\hline LEAD & Window size: 40 & & & \\
\hline SADF & $\begin{array}{l}-0.997800 \\
(0.9460) \\
\end{array}$ & 1.195182 & 1.448958 & 2.108712 \\
\hline GSADF & $\begin{array}{l}1.354989 \\
(0.4260) \\
\end{array}$ & 2.014128 & 2.265443 & 2.924275 \\
\hline NICKEL & Window size: 40 & & & \\
\hline SADF & $\begin{array}{l}-0.996898 \\
(0.9460)\end{array}$ & 1.195182 & 1.448958 & 2.108712 \\
\hline GSADF & $\begin{array}{l}1.853371 \\
(0.1470)\end{array}$ & 2.014128 & 2.265443 & 2.924275 \\
\hline ZINC & Window size: 40 & & & \\
\hline SADF & $\begin{array}{l}-0.656167 \\
(0.2740) \\
\end{array}$ & 1.195182 & 1.448958 & 2.108712 \\
\hline GSADF & $\begin{array}{l}1.885613 \\
(0.1380)\end{array}$ & 2.014128 & 2.265443 & 2.924275 \\
\hline
\end{tabular}

Critical values are based on a Monte Carlo simulation

The figures 1-5 show the futures prices in green, critical values in red and the calculated sequences in blue. Generally, the areas above the red critical values of the blue line, indicate bubble possibilities.

While the blue line does not reach the critical values in both analyzes in the aluminum contract, two analyzes for Copper and Zinc have caught upside price movements in similar places. At the Copper contract, speculative movements are observed at the end of 2010, at the beginning of 2011, and Zinc in 2016. However, the test results in Table 3 do not identify these movements as price bubbles for the whole period. The test statistics for Copper are 0.60 (SADF) and 0.93(GSADF); for Zinc 0.27(SADF) and 0.14 (GSADF). Speculative movements are captured by GSDF test in Lead prices in 2016 and Nickel prices in 2014. At the same time, these movements could not be separated from the random process according to the test results in Table 3 . The test statistics for lead are 0.95 (SADF) and 0.43 (GSADF), and for Nickel -1 (SADF) and 1.85 (GSADF). According to the figures, the speculative attacks in Lead, Nickel and Zinc do not take long periods, but the speculative attack on Cupper takes a long period. Although the test results in Table 3 do not value this attacks as bubble, the period beginning from September 2010 to February 2011 is clearly shown as bubble. 
Figure 1. SADF \& GSADF for Aluminum

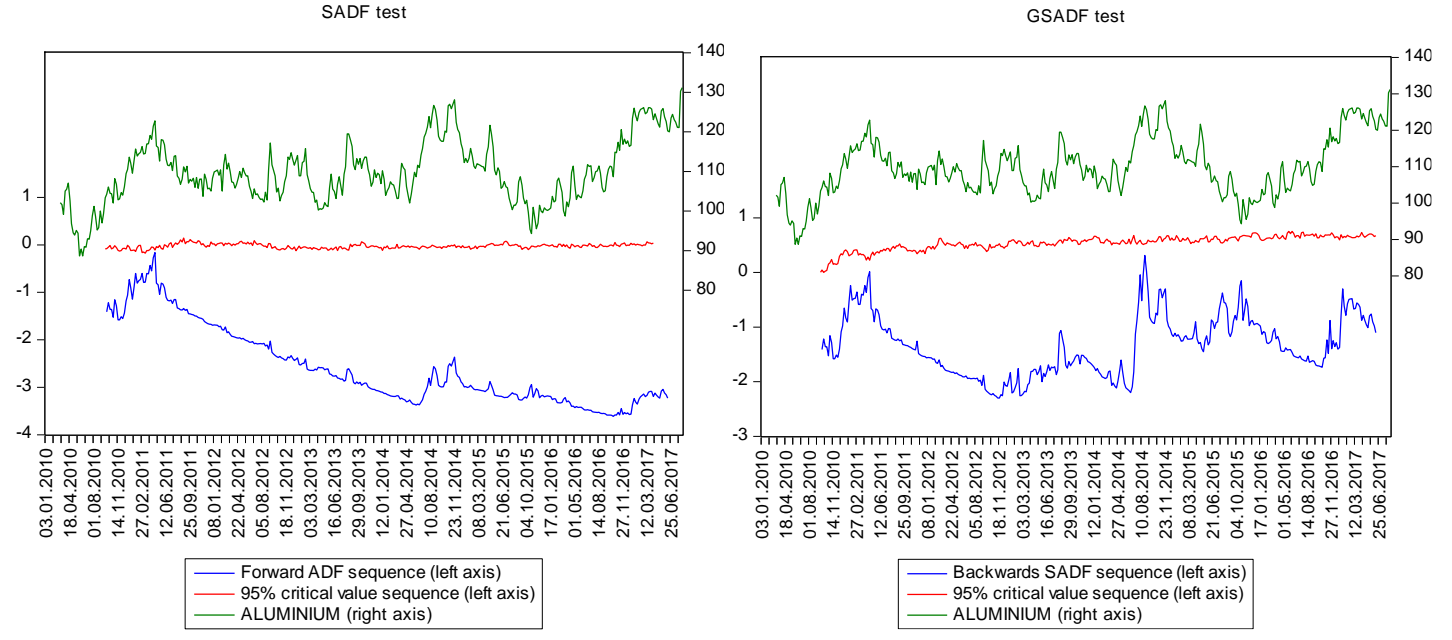

Figure 2. SADF \& GSADF for Copper GSADF test

SADF test

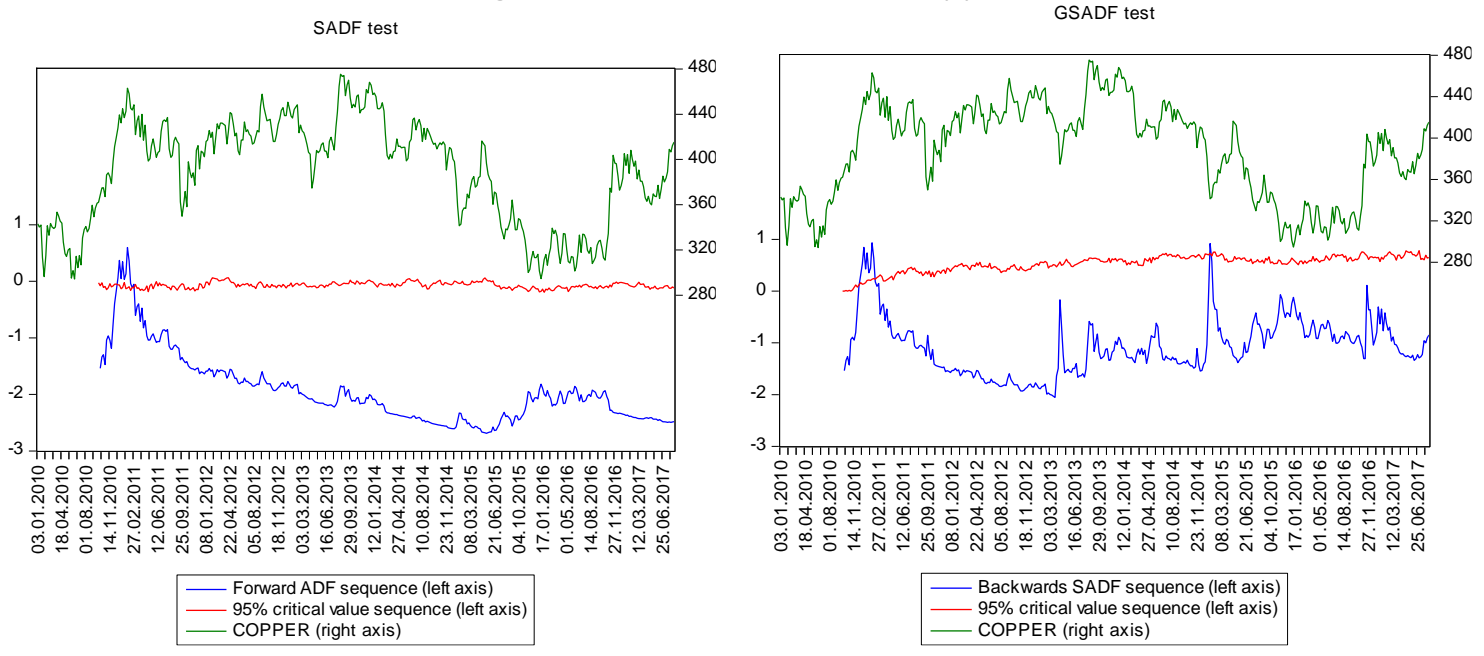

Figure 2. SADF \& GSADF for Copper

Figure 3. SADF \& GSADF for Lead

SADF test

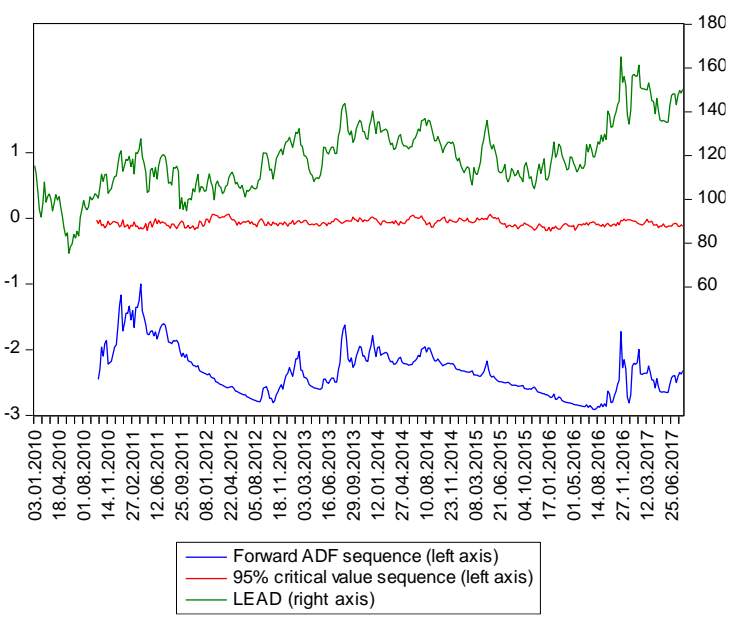

GSADF test

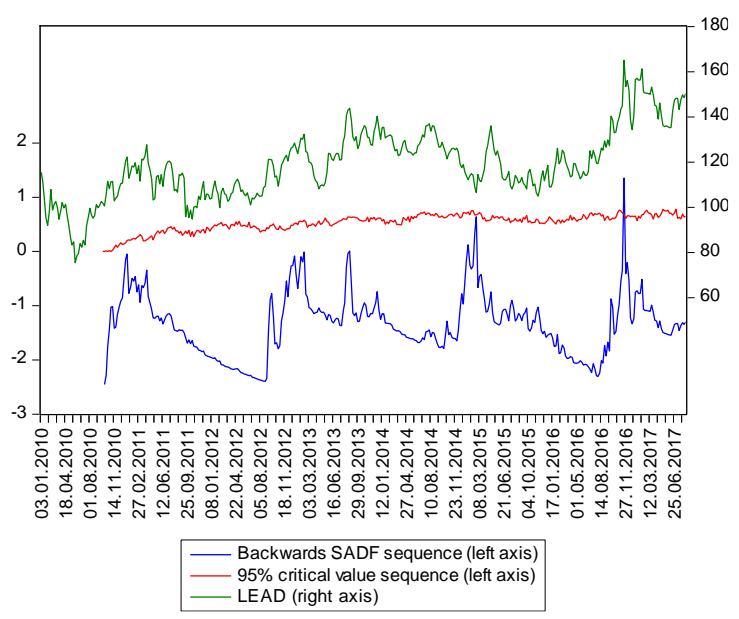


Figure 4. SADF \& GSADF for Nickel

SADF test

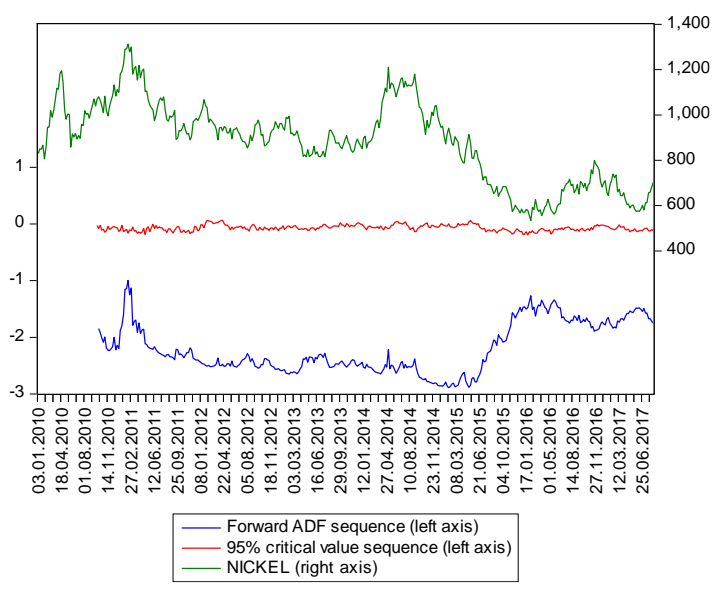

GSADF tes

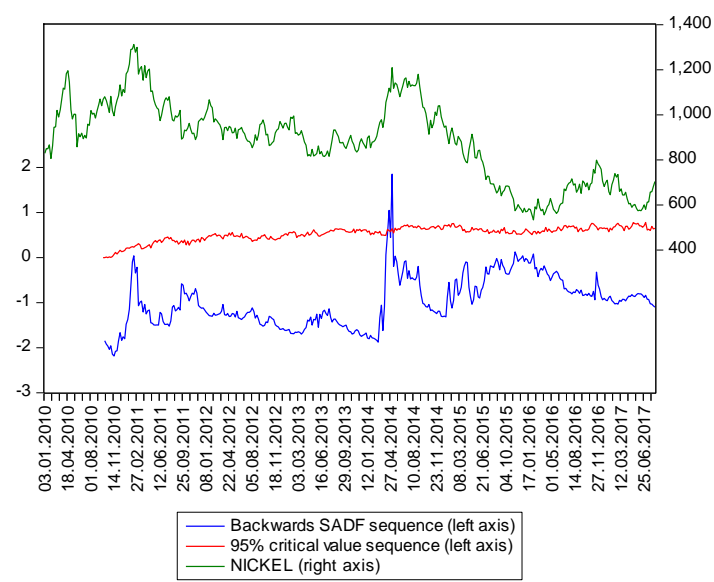

Figure 5. SADF \& GSADF for Zinc

SADF tes

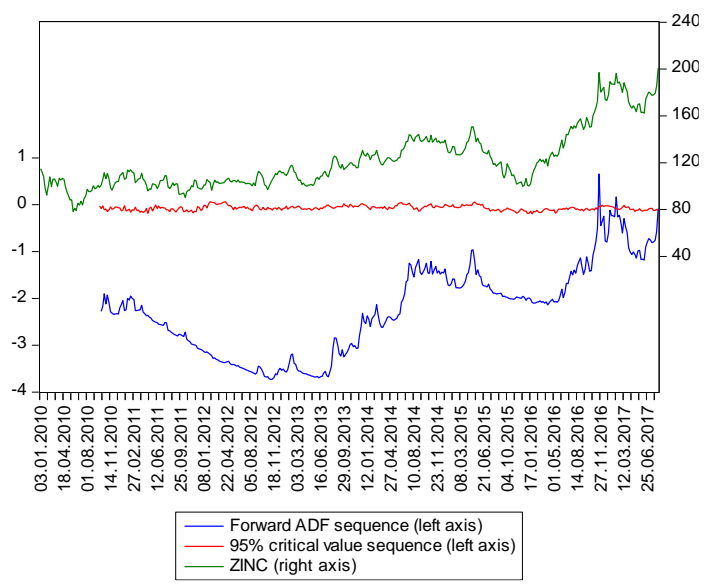

GSADF test

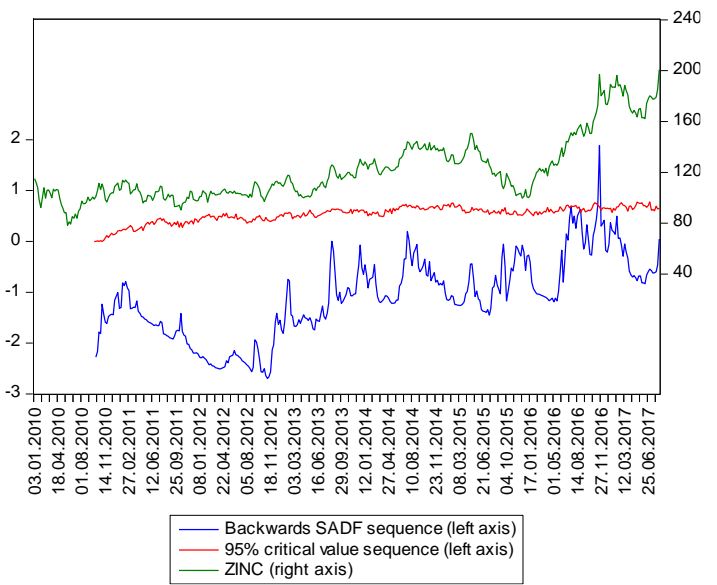

\section{Conclusions}

Most of the transactions carried out in today's derivative markets are based on financial investment. Due to their volatility differences, yield differences and low correlations with equity markets, metal futures are held for diversification in the international investors' portfolios. The mutual movement of equity markets cause investors to canalize alternative investment vehicles. In the study, the bubbles in non-precious metals futures prices as aluminum, copper, lead, nickel and zinc are detected in MCX. The period beginning from January 2010 to August 2017, for copper, lead, nickel and zinc; and the period beginning from March 2010 to August 2017 for aluminum in a weekly data range are analyzed.

Using SADF and GSADF tests, excessive price movements are found for copper, lead, nickel and zinc. Moreover, the period beginning from September 2010 to February 2011 is shown as bubble in copper futures market in India. As well as in other financial asset prices in the global financial markets, the similar price changes in commodity derivative markets are shown in different markets in the same periods. While the prices in other markets are examined, the similar rises and declines are clearly seen in all markets for the same commodity derivative instrument. In other words, the bubble identified in copper futures market in MCX in this study, and the speculative attacks in other commodity futures contracts in the sample are already exist in the US, European and other markets too. As a result, beyond determining asset bubbles, associating these bubbles with the Indian economy does not correspond to the reality of globalized financial markets. 


\section{References}

Areal, F. J., Balcombe, K. G., \& Rapsomanikis, G. (2014). Testing for bubbles in agricultural commodity markets. ESA Working Papers 14.

Arouri, M. E. H., Hammoudeh, S., Lahiani, A., \& Nguyen, D. K. (2013). On the short-and long-run efficiency of energy and precious metal markets. Energy Economics, 40, 832-844.

Arouri, M. H., \& D. N. Nguyen (2010). Oil prices, stock markets and portfolio investment: Evidence from sector analysis in Europe over the last decade. Energy Policy, 38, 4528-4539.

Baur, D. G., \& McDermott, T. K. (2010). Is gold a safe haven? International evidence. Journal of Banking \& Finance, 34(8), 1886-1898.

Baur D.G., \& Glover K.J. (2012) A gold bubble? Available at SSRN. http://www.ssrn.com/abstract=2166636. doi:10.2139/ssrn.2166636.

Bettendorf, T., \& Chen, W. (2013). Are there bubbles in the sterling-dollar exchange rate? New Evidence from sequential ADF tests. SFB 649 Discussion Paper, 2013-012, Collaborative Research Center 649: Economic Risk, Humboldt University, Berlin.

Conover, C. M., Jensen, G. R., Johnson, R. R., \& Mercer, J. M. (2010). Is now the time to add commodities to your portfolio? Journal of Invest, 19, 10-19.

Dash, M. (1999). Tulipomania: The story of the world's most coveted flower and the extraordinary passions it aroused. Three Rivers Press, New York.

Daskalaki, C., \& Skiadopoulos, G. S. (2011). Should investors include commodities in their portfolios after all? New evidence. Journal of Banking and Finance, 35, 2606-2626.

Dickey, D. A., \& Fuller, W. A. (1981). Likelihood ratio statistics for autoregressive time series with a unit root. Econometrica: Journal of the Econometric Society, 1057-1072.

Diesteldorf, J., Meyer, S., \& Voelzke, J. (2016). New evidence for explosive behavior of commodity prices. Center of Quantitative Economics, University of Muenster, 50/2016.

Escobari, D., \& Jafarinejad, M. (2015) Date stamping bubbles in real estate investment trusts. Munich Personal RePEc Archive (MPRA), 6737, https://mpra.ub.uni-muenchen.de/67372/.

Etienne, X. L., Irwin, S. H., \& Garcia, P. (2014). Bubbles in food commodity markets: Four decades of evidence. Journal of International Money and Finance, 42, 129-155.

Gilbert, C.L. (2010). Speculative influences on commodity prices. UNCTAD Discussion Paper No. 197. Geneva, Switzerland, UNCTAD.

Gutierrez, L. (2013). Speculative bubbles in agricultural commodity markets. European Review of Agricultural Economics, 40(2), 217-238.

Hammoudeh, S., Araújo-Santos, P., \& Al-Hassan, A. (2013). Downside risk management and VaR-based optimal portfolios for precious metals, oil and stocks. The North American Journal of Economics and Finance, 25, 318334.

Korkmaz, Ö., Erer, E., \& Erer, D. (2016). The factors affecting credit bubbles: The case of Turkey. Financial Studies, 20(1), 37-53.

Phillips, P.C.B., Shi, S., \& Yu, J. (2012). Testing for multiple bubbles. Cowles Foundation Discussion Paper, No. 1843

Phillips, P. C., Shi, S., \& Yu, J. (2015). Testing for multiple bubbles: Historical episodes of exuberance and collapse in the S\&P 500. International Economic Review, 56, 1043- 1078. doi:10.1111/iere.12132.

Phillips, P. C., Shi, S., \& Yu, J. (2015). Testing for multiple bubbles: Limit theory of real-time detectors. International Economic Review, 56, 1079-1134. doi:10.1111/iere.12131.

Santoni, G. J. (1987). The great bull markets 1924-29 and 1982-87: Speculative bubbles or economic fundamentals? Federal Reserve Bank of St. Louis Review, pp. 16-30.

Shiller, R. J. (1981). The use of volatility measures in assessing market efficiency. The Journal of Finance, 36(2), Papers and Proceedings of the Thirty Ninth Annual Meeting American Finance Association, Denver, pp. 291-304.

Su, C. W., Li, Z. Z., Chang, H. L., \& Lobonţ, O. R. (2017). When will occur the crude oil bubbles? Energy Policy, 102, 1-6.

Su, C. W., Wang, K. H., Chang, H. L., \& Dumitrescu-Peculea, A. (2017). Do iron ore price bubbles occur? Resources Policy, 53, 340-346

Tirole, J. (1985). Asset Bubbles and Overlapping Generations. Econometrica, 53(5), 1071-1100. 
This Page Intentionally Left Blank 